\title{
Amphibian and reptile diversity of Peleng Island, Banggai Kepulauan, Central Sulawesi, Indonesia
}

\author{
AWAL RIYANTO',2,, CAHYO RAHMADI ${ }^{1}$ \\ ${ }^{1}$ Museum Zoologicum Bogoriense, Research Center for Biology, Indonesian Institute of Sciences. Widyasatwaloka Build., Jl. Raya Jakarta-Bogor Km. \\ 46, Cibinong, Bogor 16911, West Java, Indonesia. Tel.: +62-21-876 5056, `email: awal_lizards@yahoo.com; awal.riyanto@lipi.go.id \\ ${ }^{2}$ Association of Asian Herpetology (Asosiasi Herpetologi Asia). Jl. BSD Bintaro No. 88, Pondok Aren, Tangerang Selatan 15228, Banten, Indonesia
}

Manuscript received: 1 April 2021. Revision accepted: 28 April 2021.

\begin{abstract}
Riyanto A, Rahmadi C. 2021. Amphibian and reptile diversity of Peleng Island, Banggai Kepulauan, Central Sulawesi, Indonesia. Biodiversitas 22: 2930-2939. Indonesia is an archipelagic country and is known as one of the world's megadiverse countries and has three zoogeographic zones. Therefore, proper conservation efforts to face extinction threats are very important, and the fundamental steps to better understanding it's biodiversity provide valuable baseline information. Amphibians and reptiles (herpetofauna) are main biodiversity components that experience extinction threats but, at the same time, provide an important role in ecosystems and community life. This paper is the first to provide a checklist of the herpetofauna of Peleng Island, Banggai Kepulauan, Central Sulawesi, Indonesia. Data was gathered by field surveys and supplemented by references. Visual Encounter Surveys (VES) were undertaken in 8 sites. A total of 34 species are listed herein, $29(85 \%)$ of them revealed from this fieldwork, and $21(62 \%)$ new for the island. At least two candidate new species of the genus Cyrtodactylus were confirmed by molecular data and one frog of the genus Kaloula also suspected new species.
\end{abstract}

Keywords: Checklist, herpetofauna, new species, Peleng, Sulawesi

\section{INTRODUCTION}

Indonesia is an archipelagic country, among the world's megadiverse, and extends over three zoogeographic zones. Therefore, allocation of proper conservation efforts to face threats of extinction is very important. Fundamental to this allocation is our better understanding of the distribution of species, baseline information.

The herpetofauna (amphibians and reptiles) provides a livelihood for native populations, as reported by Mittermeier et al. (2015), as example, turtles have a high value, as food, medicine, pets, and as providers of ecological services. Dharmananda (1997) and Pipeng et al.( 2013) also reported that snakes have been prized in Asia for centuries, for their meat, skin, and medicinal properties, traditionally harvested from the wild and traded on a local and sustainable scale (Pipeng et al. 2013). Regarding environmental quality, Burlibasa and Gavrilă (2011) report amphibians to be good bioindicators because they are sensitive to environmental variability. Due to low metabolic rates, high energy conversion efficiencies, and astonishing reproductive potential, the herpetofauna is extremely important in ecological food chains (Burton and Likens 1975). In summary, the herpetofauna plays an important role in ecosystems and community life.

Peleng is the biggest island on the Banggai archipelago, approximately $14 \mathrm{~km}$ south-east of eastern Sulawesi and 80 $\mathrm{km}$ west of the Sula Islands. Few herpetofauna accounts having been published on Peleng, only those of Bosch (1985) — only mentioning two snakes, Koch et al. (2009), reporting two frogs and four reptiles, McGuire et al. (2007), mentioning one lizard, Musters (1983), described a new flying lizard, Putri et al. (2019), reporting on one frog species, and Syahrullah (2018), reporting one snake and one lizard based on interview.

Peleng Island is $2.406 \mathrm{~km}^{2}$ and with various natural ecosystems, such as tropical rain forests, mangroves, coastal environments, and plantations. Presently under economic development to increase community welfare. Considering the important role of the herpetofauna in ecosystems, community life, and sustainable development, it seems important to make available an accurate and informative checklist of the reptiles and amphibians of the island. This can be used by policymakers in determining and planning the sustainable development of Peleng Island.

\section{MATERIALS AND METHODS}

\section{Study area}

The herpetofauna survey of Peleng Island, administratively belonging to Banggai Kepulauan District (kabupaten), Province of Central Sulawesi, Indonesia, was conducted from 14 to 24 September 2014, at 8 sites (for details see Table 1 and Figure 1). 
Table 1. Sampling sites on herpetofaunal survey at Peleng Island of Banggai Kepulauan District, Central Sulawesi Province, Indonesia. Specific localities followed by encompassing administrative sub-district (kecamatan).

\begin{tabular}{llll}
\hline \multicolumn{1}{c}{ Sampling sites, sub-district } & $\begin{array}{c}\text { Time of } \\
\text { search }\end{array}$ & \multicolumn{1}{c}{ Coordinate } & \multicolumn{1}{c}{ Habitat types } \\
\hline Luk Panenteng, Bulagi Utara & Night & $01^{\circ} 12^{\prime} 57.7 \mathrm{~S} ; 122^{\circ} 57^{\prime} 58.6 \mathrm{E}$ & Shrub, rocky, beach \\
Luk Sagu, Tinangkung Utara & Night & $01^{\circ} 16^{\prime} 42.9 \mathrm{~S} ; 123^{\circ} 25^{\prime} 34.0 \mathrm{E}$ & Waterfall, paddy field, shrub, coconut plantation \\
Liang cave, Liang & Night & $01^{\circ} 32^{\prime} 25.0 \mathrm{~S} ; 123^{\circ} 14^{\prime} 03.1 \mathrm{E}$ & Cave \\
Lumbi-lumbia, Buko Selatan & Night & $01^{\circ} 27^{\prime} 17.0 \mathrm{~S} ; 122^{\circ} 50^{\prime} 43.5 \mathrm{E}$ & Waterfall, secondary forest \\
Bonepuso, Bulagi Selatan & Day & $01^{\circ} 35^{\prime} 42.5 \mathrm{~S} ; 122^{\circ} 533^{\prime} 25.5 \mathrm{E}$ & Waterfall, coconut plantation, shrub \\
Patukuki, Peling Tengah & Day & $01^{\circ} 25^{\prime} 33 \mathrm{~S} ; 123^{\circ} 10^{\prime} 43 \mathrm{E}$ & Garden, cacao plantation, coconut plantation \\
Tendetung, Totikum Selatan & Day & $01^{\circ} 24^{\prime} 56.7 \mathrm{~S} ; 123^{\circ} 27^{\prime} 46.6 \mathrm{E}$ & Drying lake, coconut plantation \\
Tompudau, Tinangkung & Night & $01^{\circ} 22^{\prime} 57.4 \mathrm{~S} ; 123^{\circ} 18^{\prime} 03.5 \mathrm{E}$ & Cave, shrub, forest (KM 9-15) \\
\hline
\end{tabular}

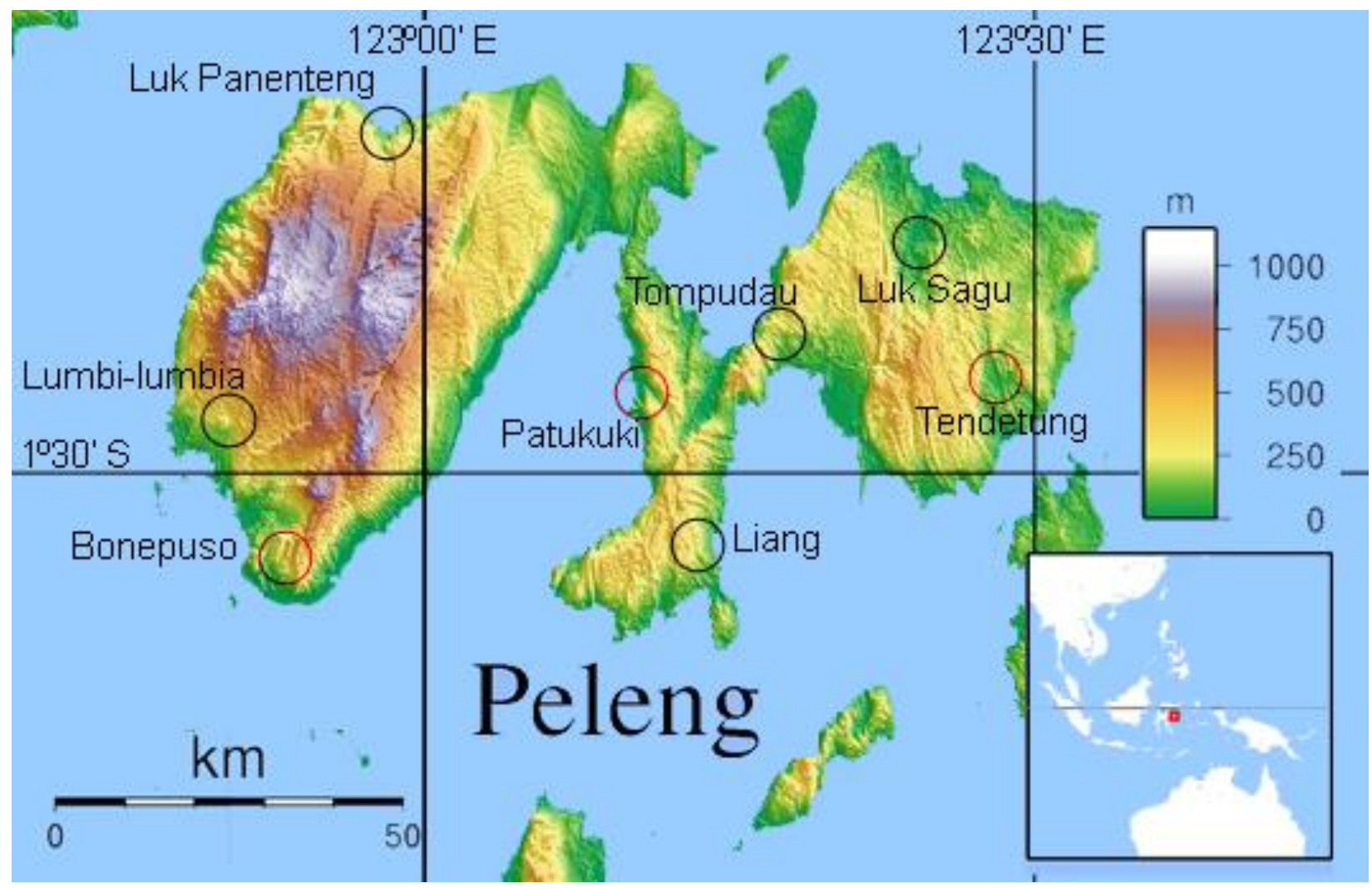

Figure 1. Map of Peleng Island showing sampling sites, Banggai Kepulauan, Central Sulawesi, Indonesia. Black circle: night surveys and red circle: day surveys. Map modified from Sadalmelik/Wikimedia Commons

\section{Data collection}

Visual Encounter Surveys (VES), opportunistic searching of the herpetofauna, was carried on the 8 sites. We conduct this method by two people and once for each site. Day searching was conducted from around 0800 to 1500 hours and night searching from 1800 to 2300 hours (East Indonesian Time).

The taxa needed further taxonomic identification at laboratory were collected by hand, euthanized with sodium pentobarbital, and fixed in $10 \%$ buffered formalin for 24 hours, and washed in running water before storage in $70 \%$ ethanol. Liver tissues for further research were taken from specimens and stored in $96 \%$ ethanol prior to specimen fixation in $10 \%$ formalin. Photographs or voucher specimens are provided for every species unless stated otherwise. All specimens were deposited at the Museum Zoologicum Bogoriense (MZB) - Research Center for Biology, the Indonesian Institute of Sciences (LIPI), Indonesia. To supplement our fieldwork, additional species occurrence and accounts were supplemented with data presented by Muster (1983), Bosch (1985), McGuire et al. (2007), Koch et al. (2009), Syahrullah (2018), Putri et al. (2019), and the MZB specimen collection.

\section{Nomenclature}

The taxonomy used herein follows Uetz et al. (2021) for reptiles and Frost (2021) for amphibians. 


\section{Conservation status}

The national conservation status of each species was checked based on Indonesian regulation (P.106/MENLHK/ SETJEN/KUM.1/12/2018), and the international conservation status according to The IUCN Red List of the Threatened Species (IUCN 2021) and Appendices of CITES (2021).

\section{RESULTS AND DISCUSSION}

\section{Herpetofaunal diversity}

A total of 34 herpetofauna species are listed from Peleng Island (Table 2), comprising eight species of amphibians, 15 species of lizards, seven snakes, one species of freshwater turtle, two species of sea turtles, and crocodile species. Our fieldwork revealed 29 species $(85 \%$ of the total) and 21 species (62\% of the total) are new reports for this island. Of the total, 3 species are listed as protected under national regulation, Crocodylus porosus (Saltwater crocodile), Chelonia mydas (Green sea turtle) and Eretmochelys imbricata (Hawksbill sea turtle), these being also listed in CITES appendix I. One snake has listed in CITES app. II, Malayopython reticulatus (Reticulated python). The IUCN Red List encompasses 15 of these species, one of them are Critically Endangered (CR): E. imbricata, and one Endangered (E): C. mydas. Ten species are endemic to Sulawesi and its adjacent islands. Two undescribed new species from the genus Cyrtodactylus are now confirmed molecularly, and 1 frog from the genus Kaloula is also suspected to be an undescribed new species. Conservation status distributions based on national legislation, CITES, and endemicity are presented in Figure 2.

\section{Species account}

Photographs of selected species can be seen in Figure 3.

\section{Amphibia}

\section{Family Ceratobatrachidae}

Cornufer papuensis (Meyer 1875) - Papua wrinkled ground frog. Snout-vent length (SVL) up to $36 \mathrm{~mm}$ in males and $50 \mathrm{~mm}$ in females. Fingers and toes are long and slender, webbing on basal toes. First finger longer than second. Dorsum with numerous short skin folds. Abundant, more than 30 individuals in each survey times and locality especially in the floor secondary forest until shrubs close Tompudau and Liang caves. The species have wide distribution in Wallacea, Papua New Guinea and Bismark Islands. Known distribution in Indonesia including Sangihe, Talaud, Seram, Halmahera, Ambon, Sula, Banggai Islands, Moluccas Islands, and Papua.
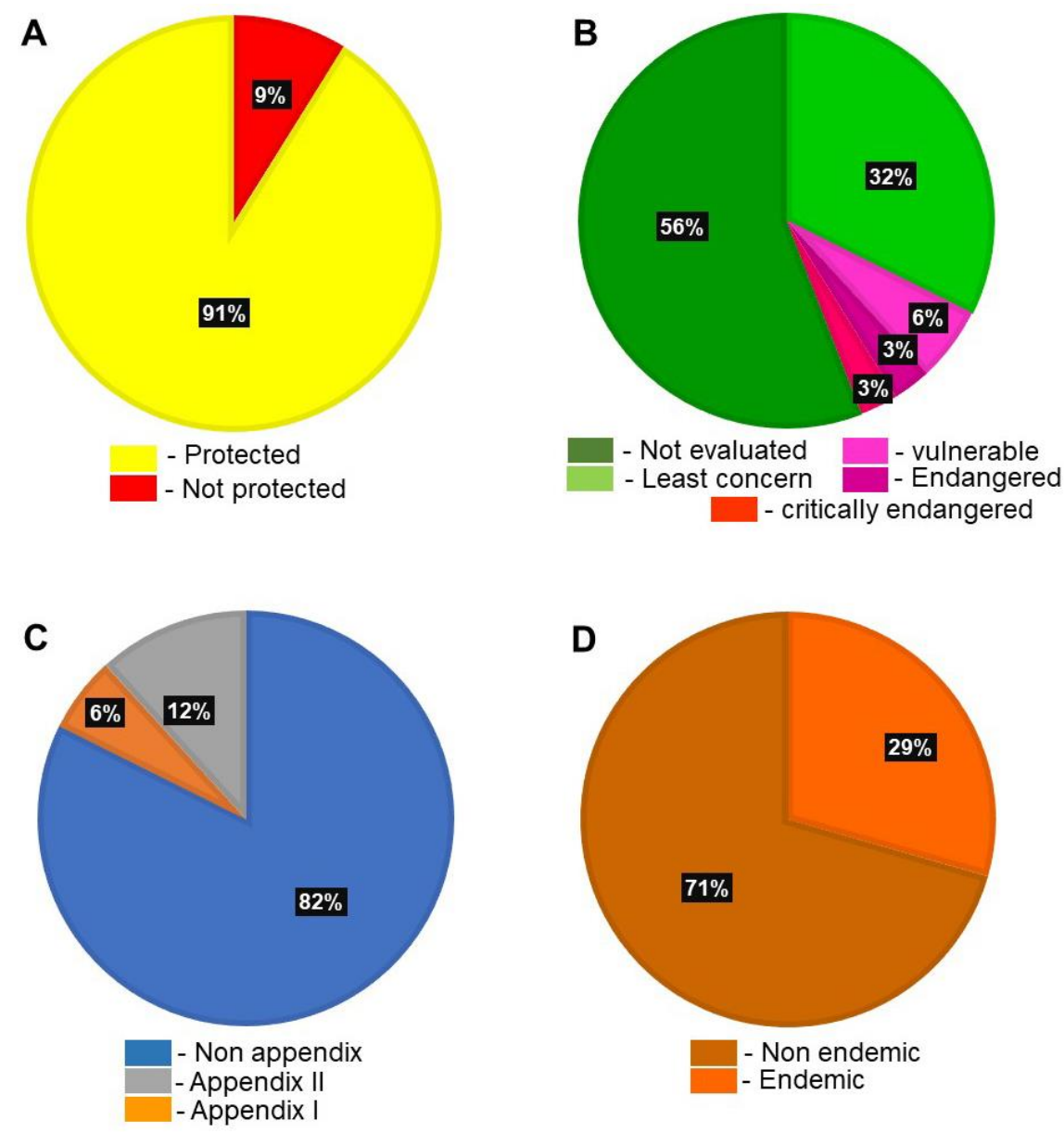

Figure 2. Conservation and endemicity status of amphibians and reptiles of Peleng Island, Banggai Kepulauan, Central Sulawesi, Indonesia. A. National Conservation status, B. IUCN status, C. CITES status, and D. Endemicity 


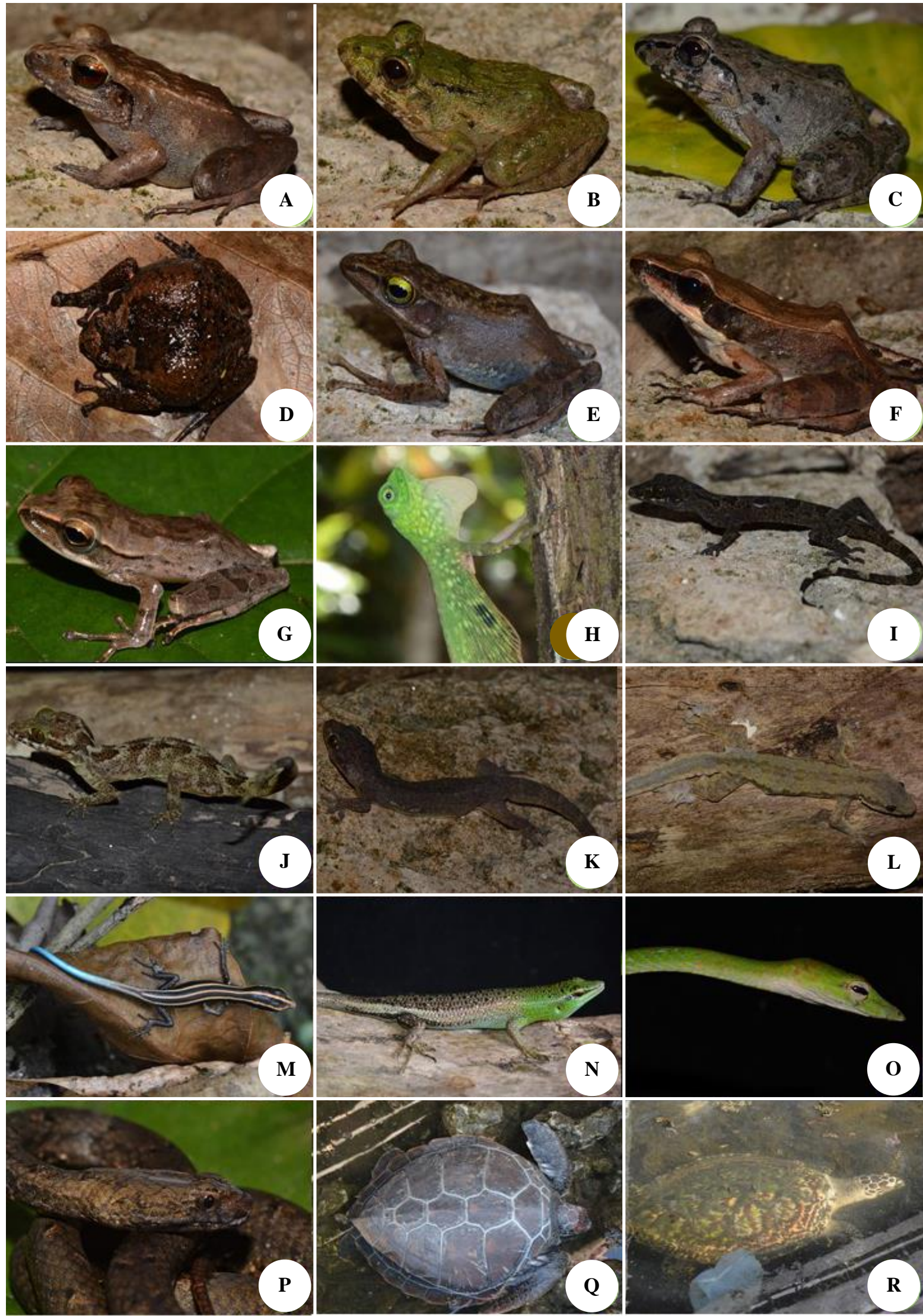

Figure 3. Amphibians and reptiles of Peleng island, Banggai Kepulauan, Central Sulawesi, Indonesia. A. Cornufer papuensis, B. Fejervarya cancrivora, C. Limnonectes modestus, D. Kaloula sp., E. Chalcorana mocquardi, F. Papurana celebensis, G. Polypedates iskandari, H. Draco rythisma, I. Cyrtodactylus sp1, J. Cyrtodactylus sp2, K. Gehyra mutilata, L. Hemidactylus platyurus, M. Emoia caeruleocauda, N. Lamprolepis smaragdina, O. Ahaetulla prasina P. Psammodynastes pulverulentus, Q. Chelonia mydas, and R. Eretmochelys imbricata 
Table 2. List amphibians and reptiles of Peleng Island, Indonesia

\begin{tabular}{|c|c|c|c|c|c|}
\hline \multirow[b]{2}{*}{ Taxa } & \multicolumn{4}{|c|}{ Status } & \multirow[b]{2}{*}{ Source } \\
\hline & $\begin{array}{c}\text { Nationally } \\
\text { protected }\end{array}$ & IUCN & CITES & $\begin{array}{c}\text { Endemic to } \\
\text { Sulawesi }\end{array}$ & \\
\hline \multicolumn{6}{|l|}{ Amphibia } \\
\hline \multicolumn{6}{|l|}{ Ceratobatrachidae } \\
\hline Cornufer papuensis Meyer 1875 & $\mathrm{x}$ & $\mathrm{LC}$ & $\mathrm{x}$ & $\mathrm{x}$ & 1,5 \\
\hline \multicolumn{6}{|l|}{ Dicroglossidae } \\
\hline Fejervarya cancrivora (Gravenhorst, 1829) & $\mathrm{x}$ & $\mathrm{LC}$ & $\mathrm{x}$ & $\mathrm{x}$ & 1 \\
\hline Limnonectes heinrichii (Ahl, 1933) & $\mathrm{x}$ & VU & $\mathrm{x}$ & $\mathrm{x}$ & 1 \\
\hline Limnonectes modestus (Boulenger, 1882) & $\mathrm{x}$ & $\mathrm{LC}$ & $\mathrm{x}$ & $\mathrm{x}$ & 1,8 \\
\hline \multicolumn{6}{|l|}{ Microhylidae } \\
\hline Kaloula sp. & $\mathrm{x}$ & NE & $\mathrm{x}$ & $\sqrt{ }$ & 1,5 \\
\hline \multicolumn{6}{|l|}{ Ranidae } \\
\hline Chalcorana moquardi (Werner, 1901) & $\mathrm{x}$ & NE & $\mathrm{x}$ & $\sqrt{ }$ & 1 \\
\hline Papurana celebensis (Peter, 1872) & $\mathrm{x}$ & $\mathrm{LC}$ & $\mathrm{x}$ & $\sqrt{ }$ & 1 \\
\hline Polypedates iskandari Riyanto, Mumpuni \& McGuire, 2011 & $\mathrm{x}$ & & & $\sqrt{ }$ & 1 \\
\hline \multicolumn{6}{|l|}{ Reptilia } \\
\hline \multicolumn{6}{|l|}{ Agamidae } \\
\hline Draco rythisma Muster, 1983 & $\mathrm{x}$ & NE & $\mathrm{x}$ & $\sqrt{ }$ & $1,6,7$ \\
\hline Hydrosaurus sp. & $\mathrm{x}$ & $\mathrm{NE}$ & $\mathrm{x}$ & $\mathrm{x}$ & 9 \\
\hline \multicolumn{6}{|l|}{ Gekkonidae } \\
\hline Cyrtodactylus sp1 & $\mathrm{x}$ & NE & $\mathrm{x}$ & $\sqrt{ }$ & 1 \\
\hline Cyrtodactylus sp2 & $\mathrm{x}$ & NE & $\mathrm{x}$ & $\sqrt{ }$ & 1 \\
\hline Gehyra mutilata (Wiegmann, 1834) & $\mathrm{x}$ & NE & $\mathrm{x}$ & $\mathrm{x}$ & 1 \\
\hline Gekko gecko (Linnaeus, 1758) & $\mathrm{x}$ & $\mathrm{NE}$ & $\mathrm{x}$ & $\mathrm{x}$ & 1 \\
\hline Gekko smithii Gray, 1842 & $\mathrm{x}$ & $\mathrm{LC}$ & $\mathrm{x}$ & $\mathrm{x}$ & 1 \\
\hline Hemidactylus frenatus Schneider, 1836 & $\mathrm{x}$ & $\mathrm{LC}$ & $\mathrm{x}$ & $\mathrm{x}$ & 1 \\
\hline Hemidactylus platyurus (Schneider, 1792) & $\mathrm{x}$ & NE & $\mathrm{x}$ & $\mathrm{x}$ & 1 \\
\hline \multicolumn{6}{|l|}{$\begin{array}{l}\text { Scincidae } \\
\end{array}$} \\
\hline Emoia atrocostata (Lesson, 1826) & $\mathrm{x}$ & NE & $\mathrm{x}$ & $\mathrm{x}$ & 1 \\
\hline Emoia caeruleocauda (De Vis, 1892) & $\mathrm{x}$ & $\mathrm{LC}$ & $\mathrm{x}$ & $\mathrm{x}$ & 1,5 \\
\hline Eutropis multifasciata (Kuhl, 1820) & $\mathrm{x}$ & NE & $\mathrm{x}$ & $\mathrm{x}$ & 1 \\
\hline Lamprolepis smaragdina (Lesson, 1830) & $\mathrm{x}$ & $\mathrm{NE}$ & $\mathrm{x}$ & $\mathrm{x}$ & 1,5 \\
\hline Lipinia infralineolata (Günther, 1873) & $\mathrm{x}$ & NE & & $\sqrt{ }$ & 5 \\
\hline \multicolumn{6}{|l|}{ Varanidae } \\
\hline Varanus salvator (Laurenti, 1768) & $\mathrm{x}$ & $\mathrm{LC}$ & II & $\mathrm{x}$ & 1,5 \\
\hline \multicolumn{6}{|l|}{ Colubridae } \\
\hline Ahaetulla prasina (Boie, 1827) & $\mathrm{x}$ & $\mathrm{LC}$ & $\mathrm{x}$ & $\mathrm{x}$ & 1 \\
\hline Boiga irregularis (Bechstein, 1802) & $\mathrm{x}$ & $\mathrm{NE}$ & $\mathrm{x}$ & $\mathrm{x}$ & 1 \\
\hline Calamaria banggaiensis Koch, Arida, McGuire, Iskandar \& Bőhme, 2009 & $\mathrm{x}$ & $\mathrm{NE}$ & $\mathrm{x}$ & $\hat{\sqrt{ }}$ & 4,5 \\
\hline Psammodynastes pulverulentus Boie, 1827 & $\mathrm{x}$ & NE & $\mathrm{x}$ & $\mathrm{x}$ & 1 \\
\hline Coelognathus erythrurus celebensis (Jan 1867) & $\mathrm{x}$ & $\mathrm{NE}$ & $\mathrm{x}$ & $\sqrt{ }$ & 3,4 \\
\hline \multicolumn{6}{|l|}{ Homalopsidae } \\
\hline Cerberus schneiderei (Schlegel, 1837) & $\mathrm{x}$ & $\mathrm{NE}$ & $\mathrm{x}$ & $\mathrm{x}$ & 3 \\
\hline \multicolumn{6}{|l|}{ Pythonidae } \\
\hline Malayopython reticulatus (Schneider, 1801) & $\mathrm{x}$ & $\mathrm{LC}$ & II & $\mathrm{x}$ & 1,9 \\
\hline \multicolumn{6}{|l|}{ Bataguridae } \\
\hline Cuora amboinensis amboinensis (Daudin, 1682) & $\mathrm{x}$ & VU & II & $\mathrm{x}$ & 1 \\
\hline \multicolumn{6}{|l|}{ Cheloniidae } \\
\hline Chelonia mydas (Linnaeus, 1758) & $\sqrt{ }$ & EN & I & $\mathrm{x}$ & 1 \\
\hline Eretmochelys imbricata (Linnaeus, 1766) & $\sqrt{ }$ & $\mathrm{CR}$ & I & $\mathrm{x}$ & 1 \\
\hline \multicolumn{6}{|l|}{$\begin{array}{l}\text { Crocodilidae } \\
\text { Pal }\end{array}$} \\
\hline Crocodylus porosus Schneider, 1801 & $\sqrt{ }$ & $\mathrm{LC}$ & II & $\mathrm{x}$ & 1 \\
\hline
\end{tabular}

Note: $\sqrt{ }$ : yes, x: no, CR: critically endangered, EN: endangered, LC: least concern, NE: not evaluated, VU: vulnerable, 1: this study, 2: Bosch (1985), 3: de Lang and Vogel (2005), 4: Koch (2011), 5: Koch et al. (2009), 6: McGuire et al. (2007), 7: Muster (1983), 8: Putri et al. (2019), and 9: Syahrullah (2018).

\section{Family Dicroglossidae}

Fejervarya cancrivora (Gravenhorst, 1829) - Ricefield frog. SVL up to $80 \mathrm{~mm}$. Rounded canthus rostralis, concave loreal region with a flat interorbital, nostrils position is closer to the tip of snout than to the eyes. Distinct tympanum with supratympanic folds and lack parotoid glands. Dorsum with warts and folds, meanwhile ventral smooth. Long fingers with blunt tips and presence 
of subarticular tubercles, meanwhile the toes have webbing and always beyond the last subarticular tubercles on the fourth toes, and without outer metatarsals. Abundant at paddy field and area close to waterfall, such as in Lok Sagu. This is one of most widely distributed frog species in the Asian region, with populations extending South of the Isthmus of Kra in Thailand, West Malaysia, Kalimantan (Borneo), Sumatra, West and Central Java, and Bali in Indonesia, with introduced populations in Papua New Guinea and Guam (Frost 2021).

Limnonectes heinrichii (Ahl, 1933) - Heinrich's wart frog. According to McLeod (2010), L. heinrichii is a species complex. Snout-vent length (SVL) up to $36 \mathrm{~mm}$. Lowlands of North Sulawesi Province, Sulawesi, Indonesia, below $600 \mathrm{~m}$ asl. The presence in Peleng Island is a new record of distribution.

Limnonectes modestus (Boulenger, 1882) - Moluccas wart frog. SVL up to $43.5 \mathrm{~mm}$. Stout body, smooth skin with dominant warts all over the body. Tympanum small and distinct. Tips of fingers blunt and not enlarged. Tips of toes blunt toes webbing. Abundant, about 25 individuals in each survey times. It's found in the small trench with sandstone substrate mixed with flowing clear water near forest and also in the streams under secondary forest. According to Menzies (1987), Gorontalo and Manado are the type localities. The species is widespread, occurring on Sulawesi, Peleng, Seram, Buru, Ambon, Obi, Bacan, Batudaka, Togian and Talatakoh, and Halmahera Islands in Indonesia, up to $1200 \mathrm{~m}$ above sea level (Frost 2021).

\section{Family Microhylidae}

Kaloula sp. - Asian narrow mouth frog. Mostly likely to $K$. baleata. SVL reached $41 \mathrm{~mm}$. The specimens have unusual character especially on the formation of subarticular on toes. The suspected undescribed species was collected from Tompudau cave.

\section{Family Ranidae}

Chalcorana mocquardi (Werner, 1901) - Mocquard true frog. SVL up to $50 \mathrm{~mm}$. Slender body, pointed snout, tympanum distinct and the dorsolateral fold less pronounced. Unlike toes, fingers not webbed. This frog only found in Sulawesi (Frost 2021).

Papurana celebensis (Peters, 1872) - Sulawesi true frog. SVL up to $48.5 \mathrm{~mm}$. Slender's body, pointed snout with distinct tympanum and dorsolateral body folds very distinctly. Fingers not webbed, whereas present on toes. Tips of finger and toes are enlarged. Distinct subarticular tubercles on toes. Body is generally brown with on canthus and tympanum are black. The upper part of the body is smooth while the sides of the body are protruding. Oliver et al. (2015) noted that this species is likely in either Hydrophylax or Indosylvirana, but pending genetic sampling declined to make any taxonomic changes. Thus, for a while, Frost (2021) removed it from "Hylarana". The frog was encountered on Luk Sagu waterfall and Lumbilumbia waterfall and its forest floor.

Polypedates iskandari Riyanto, Mumpuni \& McGuire, 2011 - Iskandar's tree frog. SVL up to $45 \mathrm{~mm}$. Unfortunately, only single individual was observed in front of Tompudau cave. According to Riyanto et al. (2011), this tree frog distributed from southern to northern Sulawesi, and Putri et al. (2019) reported that this species was found up to $1600 \mathrm{~m}$ asl at Lake Kalimpa's Lore Lindu National Park in Sulawesi Tengah. The occurrence in Peleng island is the first record of the distribution outside mainland of Sulawesi.

\section{Reptilia \\ Family Agamidae}

Draco rythisma Muster, 1983 - Banggai flying lizard. Snout vent length (SVL) up to $70 \mathrm{~mm}$ in males and $85 \mathrm{~mm}$ in females. The genus Draco has a sexual dimorphism characterized by presence of dewlap in male. According to McGuire et al. (2007), male of this species has vivid lime green coloration in dorsal; green with scattered white spots and one to three larger or less centrally located black blotches in dorsal patagial; dewlap green basally, yellow distally; dewlap short and rounded distally; lack of melanic interorbital spot, a nuchal spot, post nuchal spot and melanic eye spots on the supraorbital. Both sexes lack white pigments on the nape and the tympanum covered by scales. It was observed abundance in all sites with various habitat types from garden, plantation area (cacao, coconut, and cashew) to secondary forest. Currently, only known from Banggai and Peleng Island (Uetz et al. 2021), so the species is endemic to these small islands.

\section{Family Gekkonidae}

Cyrtodactylus Gray, 1827 - At present, there are five recognized species occur on Sulawesi and its adjasent islands, i.e., C. batik, C. fumosus, C. hitchi, C. jellesmae, C. spinosus, C. tahuna, C. tanahjampea, and C. wallacei (Uetz et al. 2021). There are two undescribed species from $C$. jellesmae complex occurring in Peleng (Cyrtodactylus sp1 and Cyrtodactylus sp2), these two undescribed species were confirmed based on molecular analysis. These two undescribed bent-toed geckos are being prepared for the formal description.

Cyrtodactylus sp1. - Bent-toed gecko. This small one with SVL reached $77 \mathrm{~mm}$ in males and $85 \mathrm{~mm}$ in females. Mostly found on the ground, on the trees about $0.53 \mathrm{~m}$ from ground in the shrub and secondary forest. Encountered very abundant along roadside in the secondary forest area KM 9 to KM13 (Tompudau), waterfall area such as Lumbi-lumbia and Luk Sagu and the rocky at Luk Panenteng.

Cyrtodactylus sp2. - Bent-toed gecko. This big one with SVL reached $100 \mathrm{~mm}$ in males and $110 \mathrm{~mm}$ in females. Differs to the Cyrtodactylus sp1, the big one mostly found above the ground such as trees and cave walls, also was relatively less abundance. The gecko was found on Liang cave, Tompudau cave, forest floor surrounding Luk Sagu waterfall.

Gehyra mutilata (Wiegmann, 1834) - Common fourclawed gecko. SVL reached $57 \mathrm{~mm}$, TL reached $57 \mathrm{~mm}$. Dorsal greyish or reddish-brown, uniform or dotted or variegated with darker, ventral uniform whitish. Head longer than broad, body and limbs moderately elongate, 
depressed, a skin fold present bordering the hind limb posteriorly. Tail depressed, upper surface covered by small flat scales and the lower surface with a median series of large transversely subcaudal scales.

Gekko gecko (Linnaeus, 1758) - Tokay gecko. Commensalist. SVL reached $140 \mathrm{~mm}$, TL reached 230 $\mathrm{mm}$. Head large, pupil vertical, body cylindrical, skin smooth, tubercles present on ventrolateral folds. In this study, the gecko was found in the house, garden, and lowland forest on KM 9. This species believed the native forest species but have good availability for adaptation on various habitat type including human habitation. It is therefore not surprising that this species has a wide distribution, including Bangladesh, India, Nepal, Bhutan, Myanmar, Thailand, Cambodia, Laos, Vietnam, Malaysia, South China, Philippines, Indonesia, Sulu Archipelago and Timor-Leste (Uetz et al. 2021).

Gekko smithii Gray, 1842 - Smith's green-eyed gecko. Total length up to $350 \mathrm{~mm}$. Eye green, body robust, head large, dorsum with scattered tubercles. Dorsal surfaces greyish brown with a transverse series of white spots. Generally, live in forested areas. In this study, the gecko found at a tree surrounding Bunepuso waterfall. Uetz et al. (2021) reported this species distributed on Thailand, Singapore, West Malaysia, Myanmar, India, Sumatra, Kalimantan, Java, and Sulawesi.

Hemidactylus frenatus Dumëril \& Bibron, 1836 Common house gecko. SVL up to $65 \mathrm{~mm}$, TL up to 70 $\mathrm{mm}$. Tail rounded with a series of keeled tubercles, subcaudal with a median series of transversely dilated plate. This house gecko is worldwide distributed in tropical and subtropical regions (Uetz et al. 2021).

Hemidactylus platyurus (Schneider, 1797) — Flattailed house gecko. SVL up to $61 \mathrm{~mm}$, TL up to $66 \mathrm{~mm}$. Body and tail depressed with enlarged transversely median subcaudal. Easily distinguished from other house gecko by presence of flaps of skin along its sides. Uetz et al. (2021) reported the gecko has wide distribution from north India through Bangladesh, Nicobar, Nepal, Bhutan, China, Sri Lanka, Taiwan, Thailand, Malaysia, Burma, Vietnam, Cambodia, Philippines, Sumatra, Java, Kalimantan, Sulawesi, Lombok, Sumbawa, Flores, Komodo, TimorLeste.

\section{Family Scincidae}

Emoia atrocostata (Lesson, 1830) - Mangrove skink. SVL up to $100 \mathrm{~mm}$, TL up to $260 \mathrm{~mm}$. Snout tapering. Dorsum grayish olive. This species easily distinguished from Eutropis by the lack of keeled scales on dorsal surface. The skink was observed on the beach especially on the mangrove area. Uetz et al. (2021) reported that the lizard distributed from Malay Peninsula, Singapore, Indonesia, Ryukyu, Philippines, New Guinea, Australia, to Pacific Island.

Emoia caeruleocauda (de Vis, 1842) - Pacific bluetailed skink. SVL up to $65 \mathrm{~mm}$. Snout short. Dorsum with dark vertebral strips in males, yellowish in females. Tail blue. Based on our survey, this lizard is relatively abundant in Peleng Island. Distributed from eastern Indonesia through New Guinea and Solomon Islands (Uetz et al. 2021).
Eutropis multifasciata (Kuhl, 1820) - Common sun skink. SVL up to $130 \mathrm{~mm}$, TL up to $220 \mathrm{~mm}$, know total length up to $2000 \mathrm{~mm}$. Limbs relatively short and tail cylindrical long. This lizard was encountered everywhere from garden in human settlements, plantation areas to secondary forest floor. Widely distributed through India, southern China, continental Southeast Asia, Malaysia, Thailand, Indonesia (Sumatra, Anambas, Natuna, Riau, Mentawai Archipelagos, Borneo, Java, Bali, the lesser Sundas, Maluku, Sulawesi, Halmahera, the Sulu, and Togian Archipelagos), Brunei, Philippines, and New Guinea (Grismer 2011; Chanard et al. 2015; Uetz et al. 2021).

Lamprolepis smaragdina (Lesson, 1830) The emerald tree skink. SVL up to $90 \mathrm{~mm}$, TL up to 215 $\mathrm{mm}$. The tree species is common and can be found in garden surrounding human, plantation until forest. Widely distributed through Wallace, the Philippines, New Guinea, Melanesia, and the West Pacific (Uetz et al. 2021). Interestingly based on research of Linkem et al. (2013), the Peleng population is placed in clade of West Pacific population.

Lipinia infralineolata (Günther, 1873) - Sulawesi lipinia. SVL up to $49 \mathrm{~mm}$, lower eyelid transparent, auricular lobules absent, body scales smoothly with about 22 midbody scale rows, middorsal strip present and 18-25 lamellae under fourth toe. Uetz et al. (2021) reported that this species distributed in Sulawesi.

\section{Family Varanidae}

Varanus salvator (Laurenti, 1768) - Asian water monitor. Total length up to $2000 \mathrm{~mm}$. Body muscular with tail compressed. Dorsal color dark brown or black with yellow spots. Sometimes with blackish band with yellow edges extending back from each eye. The species tolerant to human habitation, during fieldwork, was seen at mangroves and gardens. Uetz et al. (2021) noted the species distributed from Sri Lanka, northeast India, Bangladesh, Myanmar, Cambodia, Laos, Vietnam, China, Thailand, Malay Peninsula, Singapore, Indonesia (Sumatra, Kalimantan, Bali, Java, Lombok, Flores, Wetar and Sulawesi).

\section{Family Colubridae}

Ahaetulla prasina (Boie, 1827) - Oriental whip snake. SVL up to $1000 \mathrm{~mm}$, tail length (TL) up to $350 \mathrm{~mm}$. Head is triangular with slender neck and sharp canthus rostralis. Snout pointed, 2 to 3 loreals, one preocular, two postocular, 8 to10 supralabials with $4^{\text {th }}$ to $6^{\text {th }}$ touching the eye. Body long and slender, with imbricate unkeeled dorsal scales and enlarged vertebral scales. Tail long and thin. This arboreal snake has highly on body color phase green, grey, yellow, and brownish. The snake was encountered up to 10 individuals at one night on KM. 15, Tompudau. This species is mildly venomous but usually not harmless for humans.

Boiga irregularis (Bechstein, 1802) - Brown tree snake. SVL up to $2500 \mathrm{~mm}$. Head is broad and round, distinct from body. Eye large, vertical pupil, one loreal, one preocular, two postoculars, two to three anterior and three 
to four posterior temporals, nine to ten supralabials with $4^{\text {th }}$ to $6^{\text {th }}$ or $3^{\text {rd }}$ to $5^{\text {th }}$ touching the eye. Long and slender body, with enlarged vertebral scales. Dorsal color light brown to yellow. The snake inhabits from beach to forest. According to de Lang \& Vogel (2005) and Uetz et al. (2021), this species distributed on Sulawesi, Buton Island, Sangihe Islands, Moluccas (Ambon, Aru, Halmahera, Gag, Morotai, Kai, Buru, Boano, Bacan, Salawati and Seram Islands), Papua also southwards to parts of Australia, and Guam (introduce). Peleng is the first official report.

Calamaria banggaiensis Koch, Arida, McGuire, Iskandar \& Böhme, 2009 - Banggai reed snake. SVL up to $189 \mathrm{~mm}$. Preocular absent, five supralabials and mental not touching anterior chin shields. Morphologically most similar to $C$. ceramensis, differs in higher number of ventral scales (157 versus 139 in male and 198 versus 147 in female) and lower tail ratio (0.103 versus $0.125-0.150$ in male and 0.060 versus $0.07-10.081$ in female). Inhabit under decomposing log and under a rock in cacao plantation only a few meters above sea level (Koch et al. 2009). Currently, only known from Banggai and Peleng Islands (Uetz et al. 2021).

Psammodynastes pulverulentus (Boie, 1827) Common mock viper. SVL up to $770 \mathrm{~mm}$. Head is elongated and distinct from body. The snake inhabits shrub to mountain forest up to $1600 \mathrm{~m}$ elevation. This backfanged snake is active both day and night, with preys' frogs, geckos, and skinks. The snake characterized by light to dark brown or greyish and bifurcating pattern on top of head. Light dan dark brown stripes extend along body. Distributed from Indian subcontinent, Indochina, parts of southern China, Malay peninsula, most of Indonesian archipelagos and Philippines (Uetz et al. 2021).

Coelognathus erythrurus celebensis (Jan 1863) Reddish rat snake. Bosch (1985) and de Lang \& Vogel (2005) were listed the species present on Peleng island. But unfortunately, during our fieldwork not yet met. SVL up to $1400 \mathrm{~mm}$. Head slender and slightly set off the neck, snout rounded, approximately twice as long as the diameter of eyes. Eyes relatively large, round pupil with golden brown iris, one loreal, two preoculars, one preocular, two temporals in the first row and two or three in the second row, nine supralabials with $4^{\text {th }}$ to $6^{\text {th }}$ touching the eye. Body slender with smooth or slightly keeled scales, Tail long and slender (de Lang and Vogel 2005). The snake is endemic to Sulawesi and it is ejected small islands (de Lang and Vogel 2005; Uetz et al. 2021).

\section{Family Homalopsidae}

Cerberus schneiderei (Schlegel, 1837) — Dog-faced water snake. SVL up to $1000 \mathrm{~mm}$. Cylindrical with a 'neck' and a broad head, grey, brown, or olive, with a dark streak passes through the eye to the neck. This species inhabits mangrove, ponds along coastal. Murphy et al. (2012) reported that the snake distributed in Malay Peninsula, Thailand, Sumatera, Java, Kalimantan, Sulawesi, Halmahera, Sanana, Obi, and Lesser Sunda islands.

\section{Family Pythonidae}

Malayopython reticulatus (Schneider, 1801) Reticulated python. The species is the longest snake in the world, the snake characterized by its reticulate color pattern. According to Uetz et al. (2021), there are three subspecies, i.e., M. reticulatus reticulatus, M. reticulatus jampeanus (endemic to Tanahjampea Island), and $M$. reticulatus saputrai (endemic to Selayar Island). In Indonesia, the species was long time for food and skin trade, but several localities reported incidentally preying farm animals even preying on human.

\section{Family Bataguridae}

Cuora amboinensis amboinensis (Daudin, 1682) Amboina box turtle. Carapace straight length up to 250 $\mathrm{mm}$. C. amboinensis characterized by the presence of yellow lines on the head that bordering upper and lower parts of cheeks. Another distinctive feature is the head can be pulled into the body and the abdominal shield can be completely closed, so the head can be perfectly protected. Habitats vary from slow to moderate currents, paddy field, ponds, and swamps.

\section{Family Cheloniidae}

Chelonia mydas (Linnaeus, 1758) - Green turtle. Carapace length reached $1140 \mathrm{~mm}$. The species is the largest in family Cheloniidae with largest was recorded up to $1520 \mathrm{~mm}$. The turtle characterized by only one pairs of prefrontal scale, four pairs of coastal scale on carapace, and four pairs of inframarginal scale on plastron. The turtle was reported as bycatch by the fisherman in Peleng Island.

Eretmochelys imbricata (Linnaeus, 1766) - Hawksbill turtle. Carapace length reached $890 \mathrm{~mm}$. The turtle characterized by only two pairs of prefrontal scale, four pairs of coastal scale on carapace and four pairs of inframarginal scale on plastron. Imbricate scale on carapace. The turtle was recorded bycatch fisherman in Peleng Island.

\section{Discussion}

The checklist we formed is the first comprehensive list of herpetofauna for Peleng Island, and we hope these results will be helpful as preliminary data for further taxonomic studies and environmental assessments and policy-making for ongoing development projects in the island. The three unnamed species discovered from this survey are currently under preparation for formal description.

Recently, two new species and one new sub-species of bird were described from this island, i.e., Phylloscopus suaramerdu, Rhipidura habibiei, and Phyllergates cucullats relictus by Rheindt et al. (2020). The discovery of new species of birds for Indonesia is remarkable, considering that the taxonomy is arguably stable. These birds were discovered in Peleng Island, then this will greatly open an opportunity for the discovery of new species from other vertebrates, such as amphibians and reptiles. The reptile fauna of Sulawesi is one of the least known in Southeast Asia (Amarasinghe et al. 2015). According to Koch (2012), about $60 \%$ of the known snake 
fauna from Sulawesi is endemic, although this is likely to be underestimated. Given the biogeographical complexity of Sulawesi and adjacent islands with poorly known fragmented rainforests, more undescribed species may be found. Since, we conducted the survey for a limited time period, we assume surveys on longer durations, and different climatic seasons, and more diverse habitat types will yield more species to this checklist. Therefore, here we suggest more intensive surveys with increased sampling effort, especially with quantitative sampling methods such as belt transects and quadrat sampling, as well as on comprehensive taxonomic study which involving morphological and molecular analysis methods. Those methods have been general widely applied in reptiles (Grismer et al. 2012, 2014, 2016, 2018, 2019; Oliver et al. 2012, 2018; Riyanto et al. 2015, 2019; Luu et al. 2016; Agarwal et al. 2018; Nazarov et al. 2018; Davis et al. 2019; Murdoch et al. 2019; Pham et al. 2019), and amphibians (Smart et al. 2017; Wostl et al. 2017; Hamidy et al. 2018; Munir et al. 2018, 2019, 2020).

Together with two endemic mammals i.e., Tarsius pelengensis, and Rattus pelurus (Musser and Carleton 2005; Shekelle et al. 2008) and birds (Corvus unicolor, Phylloscopus suaramerdu, Rhipidura habibiei, and Phyllergates cucullats relictus) data, the Peleng Island which has wide only approximately $2.406 \mathrm{~km}^{2}$ to be high fauna endemicity island. Bird Life International declared that this island together Banggai Islands and Sula islands as one of the Endemic Bird Areas (EBA) in Indonesia, especially in Wallacea region.

On other hand, Hasanah et al. (2020) applied Enhanced Vegetation Index (EVI) images to analyze Landsat satellite images from 1991 to 2014, and that study revealed the forests of Peleng is rapidly degraded, especially in lower altitudes. Based on their study, $48 \%$ of Peleng's forests were highly degraded, $28 \%$ were moderately degraded, and $24 \%$ were less degraded. Most of our surveys conducted within the areas identified as highly degraded. This is a signal that should be a concern in order to make development plans and its implementation that is by not sacrificing the forest.

Therefore, for development to run well, prosperity is always achieved in harmony with the natural environment, suggested that among stakeholders which involves local governments, the Ministry of Environment and Forestry, local people, local NGO, and academics to formulate the development plans, protection and conservation of the area based on scientific studies and biodiversity point of view. The results of the project especially the list and distribution of the herpetofauna in Peleng Island had been used in developing local decree on protection and management of karst ecosystem in Banggai Kepulauan (Banggai Islands Regional Regulation No. 16 of 2019).

\section{ACKNOWLEDGEMENTS}

This works was funded by Badan Pengelolaan Lingkungan Hidup Daerah (BPLHD) Kabupaten Banggai Kepulauan in joint research cooperation with Research
Center for Biology, Indonesian Institute of Sciences under MOU No. 14/MOU/2014 and 1687/IPH.1/KS.02/VII/2014, and led by CR. We grateful to Ferdy Salamat who made this cooperation was successful and fruitful. We thank all team members from RC Biology LIPI and all administrative staff in BPLHD Banggai Kepulauan. We thank AA Thasun Amarasinghe (Research Center for Climate Change, University of Indonesia, Depok), Eric N Smith (The Amphibian and Reptile Diversity Research Center and Department of Biology, University of Texas at Arlington, USA), an anonymous reviewer, and editor for helpful comments that improved the quality of this manuscript. The authors have contributed equality.

\section{REFERENCES}

Agarwal I, Mahony S, Giri VB, Chaitanya R, Bauer AM. 2018. Six new Cyrtodactylus (Squamata: Gekkonidae) from Northeast India. Zootaxa 4524: 501-535. DOI:10.11646/zootaxa.4524.5.1.

Amarasinghe AAT, Vogel G, McGuire JA, Sidik I, Supriatna J, Ineich I. 2015. Description of a Second Species of the Genus Rabdion Dume' ril, Bibron \& Dume' ril, 1854 (Colubridae: Calamariinae) from Sulawesi, Indonesia. Herpetologica 71 (3): 234-239. DOI: 10.1655/HERPETOLOGICA-D-14-00058.

Bosch H. 1985. Snake of Sulawesi: Checklist, key, and additional biogeographical remarks. Zool Verh 217 (7): 1-50.

Boulenger GA. 1882. Catalogue of the Batrachia Salientia s. Ecaudata in the Collection of the British Museum. 2nd ed. Taylor and Francis, London.

Burlibasa L, Gavrila L. 2011. Amphibians as model organisms for study environmental genotoxicity. Appl Ecol Environ Res 9 (1): 1-15.

Burton, T. M., and G. E. Likens. 1975. Energy flow and nutrient cycling in salamander populations in the Hubbard Brook Experimental Forest, New Hampshire. Ecology 56: 1068-1080.

CITES. 2021. The CITES Appendices. www. cites.org/eng/app/index.php

Chanard T, Parr JWK, Nabhitabhata. 2015. A Field Guide to the Reptiles of Thailand. Oxford University Press, NY.

Davis HR, Bauer AM, Jackman TR, Nashriq I, Das I. 2019. Uncovering karst endemism within Borneo: Two new Cyrtodactylus species from Sarawak, Malaysia. Zootaxa 4614: 331-352. DOI: 10.11646/zootaxa.4614.2.4

De Lang R, Vogel G. 2005. The Snake of Sulawesi, A Field Guide to the Land Snake of Sulawesi with Identification Keys. Edition Chimaira, Germany.

Dharmananda S. 1997. The medicinal use of snakes in China. www.itmonline.org/arts/snakes.htm

Frost DR. 2021. Amphibian Species of the World 6.1, an Online Reference. American Museum of Natural History, New York, USA. DOI: $10.5531 / \mathrm{db} . v z .0001$.

Grismer LL, Wood PLJ, Thura MK, Oaks JR, Lin A. 2019. A new species of Bent-toed Gecko (Squamata, Gekkonidae, Cyrtodactylus) from the Shan Plateau in Eastern Myanmar (Burma). Zootaxa 4624: 301-321. DOI: 10.11646/zootaxa. 4624.3.1.

Grismer LL, Wood PLJ, Anuar S, Grismer MS, Quah E, Murdoch M, Muin M, Davis H, Puntriano C, Klabacka R, Cobos A, Aowphol A, Sites J, Jack. 2016. Two new Bent-toed Geckos of the Cyrtodactylus pulchellus complex from Peninsular Malaysia and multiple instances of convergent adaptation to limestone forest ecosystems. Zootaxa 4105: 401-429. DOI: 10.11646/zootaxa.4105.5.1.

Grismer LL, Wood PLJ, Anuar S, Quah ESH, Muin MA, Mohamed M, Onn CK, Sumarli AX, Loredo AI, Heinz HM. 2014. The phylogenetic relationships of three new species of the Cyrtodactylus pulchellus complex (Squamata: Gekkonidae) from poorly explored regions in Northeastern Peninsular Malaysia. Zootaxa 3786: 359-381. DOI: 10.11646/zootaxa.3786.3.6.

Grismer LL, Wood PLJ, Quah ESH, Muin MA, Sumontha M, Ahmad N, Bauer AM, Wangkulangkul S, Grismer JL, Pauwels OSG. 2012. A phylogeny and taxonomy of the Thai-Malay Peninsula Bent-toed Geckos of the Cyrtodactylus pulchellus complex (Squamata: Gekkonidae): Combined morphological and molecular analyses with 
descriptions of seven new species. Zootaxa 3520: 1-55. DOI: 10.11646/zootaxa.3520.1.1.

Grismer LL, Wood PLJ, Thura MK, Zin T, Quah ESH, Murdoch ML, Grismer MS, Lin A, Kyaw H, Lwin N. 2018. Twelve new species of Cyrtodactylus Gray (Squamata: Gekkonidae) from isolated limestone habitats in East-Central and Southern Myanmar demonstrate high localized diversity and unprecedented microendemism. Zool J Linn Soc 182: 862-959. DOI: 10.1093/zoolinnean/zlx057.

Hamidy A, Munir M, Mumpuni, Rahmania M, Kholik AA. 2018 Detection of cryptic taxa in the genus Leptophryne (Fitzinger, 1843) (Amphibia; Bufonidae) and the description of a new species from Java, Indonesia. Zootaxa 4450: 427-444. DOI: DOI:10.11646/zootaxa.4450.4.2.

Hasanah A, Supriatna, Indrawan M. 2020. Assessment of tropical forest degradation on a small island using the enhanced vegetation index. IOP Conf Ser Earth Environ Sci 481: 012061. DOI:10.1088/17551315/481/1/012061.

IUCN. 2021. The IUCN Red List of Species Threatened. www.iucnredlist.org.

Koch A. 2011. The amphibians and reptiles of Sulawesi: Underestimated diversity in a dynamic environment. In: Zachos F, Habel JC (eds) Biodiversity Hotspots, Distribution and Protection of Conservation Priority Areas. Springer, Berlin. DOI: 10.1007/978-3-642-209925_20.

Koch A. 2012. Discovery, Diversity, and Distribution of the Amphibians and Reptiles of Sulawesi and its Offshore Islands. Edition Chimaira, Germany.

Koch A, Arida E, McGuire JA, Iskandar DT. 2009. A new species of Calamaria (Squamata: Colubridae) similar to C. ceramensis de Rooij, 1913, from the Banggai Islands, east of Sulawesi, Indonesia. Zootaxa 2196: 19-30. DOI: 10.11646/zootaxa.2196.1.2.

Linkem CW, Brown RM, Siler CD, Evans BJ, Austin CC, Iskandar DT, Diesmos AC, Supriatna J, Andayani N, McGuire JA. 2013. Stochastic faunal exchanges drive diversification in widespread Wallacean and Pacific island lizards (Squamata: Scincidae: Lamprolepis smaragdina). J Biogeogr 40: 507-520. DOI:10.1111/jbi.12022.

Luu V, Bonkowski M, Nguyen T, Le M, Schneider N, Ngo H, Ziegler T. 2016. Evolution in karst massifs: Cryptic diversity among bent-toed geckos along the Truong Son Range with descriptions of three new species and one new country record from Laos. Zootaxa 4107: 101140. DOI: $10.11646 /$ zootaxa.4107.2.1.

McLeod DS. 2010. Of least concern? Systematics of a cryptic species complex: Limnonectes kuhlii (Amphibia: Anura: Dicroglossidae). Mol Phylogenet Evol 56: 991-1000. DOI: 10.1016/j.ympev.2010.04.004.

McGuire JA, Brown RM, Mumpuni, Riyanto A, Andayani N. 2007. The flying lizards of the Draco lineatus group (Squamata: Iguana: Agamidae): A taxonomic revision with description of two new species. Herpetol Monogr 21: 179-212. DOI: 10.1655/07-012.1.

Munir M, Hamidy A, Farajallah A, Smith EN. 2018. A new Megophrys Kuhl and Van Hasselt (Amphibia: Megophryidae) from Southwestern Sumatra, Indonesia. Zootaxa 4442 (3): 389-412. DOI: 10.11646/zootaxa.4442.3.3

Munir M, Hamidy A, Matsui M, Iskandar DT, Sidik I, Shimada T. 2019 A new species of Megrophrys Kuhl \& van Hasselt (Amphibia: Megophyidae) from Borneo allied to M. nasuta (Schlegel, 1858). Zootaxa 4679 (1): 001-024. DOI: 10.11646/zootaxa.4679.1.1.

Menzies JI. 1987. A taxonomic revision of Papuan Rana (Amphibia: Ranidae). Australian J Zool 35: 373-418.

Munir M, Hamidy A, Matsui M, Kusrini MD, Nishikawa K. 2020. New species of Micryletta (Amphibia: Anura) from Sumatra, Indonesia. Zool Sci 37: 1-7. DOI:10.2108/zs200006

Murdoch ML, Grismer LL, Wood JrPL, Neang T, Poyarkov NA, Tri NV, Nazarov RA, Aowphol A, Pauwels OSG, Nguyen HN, Grismer JL. 2019. Six new species of the Cyrtodactylus intermedius complex (Squamata: Gekkonidae) from the Cardamom Mountains and associated highlands of Southeast Asia. Zootaxa 4554: 1-62. DOI: 10.11646/zootaxa.4554.1.1

Murphy JC, Voris HK, Karns DR. 2012. The dog-faced water snakes, a revision of the genus Cerberus Cuvier, (Squamata, Serpentes, Homalopsidae), with the description of a new species. Zootaxa 3484 1-34. DOI: $10.11646 /$ zootaxa.3484.1.1
Musser GG, Carleton MD. 2005. Superfamily Muroidea. In: Wilson DE, Reeder DM (eds). Mammal Species of the World: A Taxonomic and Geographic Reference. 3rd ed. Johns Hopkins University Press, New York.

Musters. 1983. Taxonomy of the genus Draco L. (Agamidae, Lacertilia, Reptilia). Zool Verh 199: 1-120.

Nazarov RA, Pauwels OSG, Konstantinov EL, Chulisov AS, Orlov NL, Poyarkov NA. 2018. A new karst-dwelling bent-toed gecko (Squamata: Gekkonidae: Cyrtodactylus) from Xiangkhoang Province, Northeastern Laos. Zool Res 39: 202-219. DOI: 10.24272/j.issn.20958137.2018.010

Oliver L, Prendini E, Kraus F, Raxworthy CJ. 2015. Systematics and biogeography of the Hylarana frog (Anura: Ranidae) radiation across tropical Australasia, Southeast Asia, and Africa. Mol Phylogenet Evol 90: 176-192.

Oliver PM, Richards SJ, Sistrom M. 2012. Phylogeny and systematics of Melanesia's most diverse gecko lineage (Cyrtodactylus, Gekkonidae, Squamata). Zool Scr 41: 437-454. DOI: 10.1111/j.14636409.2012.00545.x.

Oliver PM, Travers SL, Richmond JQ, Pikacha P, Fisher RN, 2018. At the end of the line: Independent overwater colonizations of the Solomon Islands by a hyperdiverse trans-Wallacean lizard lineage (Cyrtodactylus: Gekkota: Squamata). Zool J Linn Soc 182: 681-694. DOI: 10.1093/zoolinnean/zlx047.

Pham AV, Le MD, Ziegler T, Nguyen TQ. 2019. A new species of Cyrtodactylus (Squamata: Gekkonidae) from northwestern Vietnam. Zootaxa 4544: 360-380. DOI: 10.11646/zootaxa.4544.3.3.

Putri AA, Fahri, Annawaty, Hamidy A. 2019. Ecological investigations and diversity of amphibians in Lake Kalimpa'a, Lore Lindu National Park, Central Sulawesi. J Nat Hist 53 (41-42): 2503-2516. DOI: 10.1080/00222933.2019.1705930.

Republic of Indonesia. 2019. Local Government Regulation of Banggai Kepulauan Regency. Number 16/2019. Regional secretary of Banggai Kepulauan Regency, Salakan. [Indonesian]

Republic of Indonesia. 2018. Ministerial Regulation of the Ministry of Environment and Forestry. Number $P$ 106/MENLHK/SETJEN/KUM.1/12/2018. General Director of Directorate General for Legislation, Jakarta. [Indonesian]

Rheindt FE, Prawiradilaga DM, Ashari H, Suparno, Gwee CY, Lee GWX, Wu MY, Ng NSR. 2020. A lost world in Wallacea: Description of a montane archipelagic avifauna. Science 367: 167-170. DOI: $10.1126 /$ science.aax2146.

Riyanto A, Grismer LL, Wood PLJ. 2015. The fourth Bent-toed Gecko of the genus Cyrtodactylus (Squamata: Gekkonidae) from Java, Indonesia. Zootaxa 4059: 351-363. DOI: 10.11646/zootaxa.4059.2.6.

Riyanto A, Mumpuni, McGuire JA. 2011. Morphometry of striped tree frogs, Polypedates leucomystax (Gravenhorst, 1829) from Indonesia with description of a new species. Russ J Herpetol 18: 29-35.

Riyanto A, Munir M, Martamenggala AIS, Fitriana YS, Hamidy A. 2019. Hiding in plain sight on Gunung Muria: A new species and first record of Rock gecko (Cnemaspis Strauch, 1887; Squamata, Gekkonidae) from Java, Indonesia. Zootaxa 4608 (1): 155-173. DOI: 10.11646/zootaxa.4608.1.9.

Shekelle M, Salim A, Groves CP, Indrawan M. 2008. Tarsius pelengensis. The IUCN Red List of Threatened Species 2008: e.T21494A9290015. DOI:10.2305/IUCN.UK.2008.RLTS.T21494A9 290015.en. www. iucnredlist.org/species/21494/17977515.

Smart U, Sarker GC, Arifin U, Harvey MB, Sidik I, Hamidy A Kurniawan N, Smith EN. 2017. A new genus and two new species of arboreal toads from the highlands of Sumatra with a phylogeny of Sundaland toad genera. Herpetologica 73: 63-75. DOI: 10.1655/HerpetologicaD-16-00041.

Syahrullah FN. 2018. Habitat, Population, and Distribution Lakasinding (Tarsius pelengensis) in Peleng Island Central Sulawesi. [Thesis]. Departemen Konservasi Suberdaya Hutan dan Ekowisata, Fakultas Kehutanan, Institut Pertanian Bogor. [Indonesian]

Uetz P, Freed P, Hosek J. 2021. The reptile database. www. reptiledatabase.org.

Wostl E, Riyanto A, Kurniawan N, Smith EN, Harvey MB. 2017. A taxonomic revision of the Philautus (Anura: Rhacophoridae) of Sumatra with the description of four new species. Herpetol Monogr 31 (1): 98-141. DOI: 10.1655/HERPMONOGRAPHS-D-16-00007. 